\title{
ANTIOXIDANT POTENTIAL OF POLYSACCHARIDE ISOLATED FROM METHANOLIC EXTRACT OF TINOSPORA CORDIFOLIA STEM BARK
}

\author{
ANTONY LUDAS ${ }^{1}$, SABAPATHY INDU ${ }^{1}$, SEKAR HINDUJA ${ }^{1}$, ANTHONISAMY KUMARI NIRMALA ${ }^{1}$, \\ MANIKKAM RAJALAKSHMI ${ }^{2 *}$
}

${ }^{1}$ Department of Biotechnology and Bioinformatics, Holy Cross College (Autonomous), Tiruchirappalli, India, ${ }^{2}$ Department of Zoology, Holy Cross College (Autonomous), Tiruchirappalli, Tamil Nadu, India, . Email: mdraji@gmail.com

Received: 27 March 2017, Revised and Accepted: 04 July 2018

ABSTRACT

Objective: Investigation of the antioxidant efficacy of a novel polysaccharide isolated from the methanolic extract of Tinospora cordifolia stem bark with reference to its action as free radical scavengers using in vivo and in vitro approaches was performed in the study.

Methods: Lipid peroxidation (TBARS), superoxide dismutase (SOD), catalase (CAT), and glutathione peroxidase (GPx) levels were determined with and without polysaccharide treatment in the cell lines and breast and liver tissues. 7, 12-Dimethylbenz $(\alpha)$ anthracene-induced albino Wistar rats were used as animal models.

Results: The $\mathrm{IC}_{50}$ concentration of polysaccharide was $100 \mu \mathrm{M}$ for both the cell lines. The lipid peroxidation levels were decreased in both breast cancer cell lines and liver and breast tissues. Polysaccharide treatment showed remarkably low levels of TBARS in breast cancer cells, and a significant reduction in the activity of SOD, GPx, and CAT levels in cancer groups was found to be increased with polysaccharide treatment. The alteration was found to be induced in MCF-7 and MDA-MB-231 cell lines and in breast and liver tissues of in vivo models.

Conclusion: The results showed that the polysaccharide from T. cordifolia has antioxidant potential on human breast cancer cell lines and tissues with induction of apoptosis.

Keywords: Phytotherapy, Apoptosis, Antioxidant, Free radicals.

(c) 2018 The Authors. Published by Innovare Academic Sciences Pvt Ltd. This is an open access article under the CC BY license (http://creativecommons. org/licenses/by/4. 0/) DOI: http://dx.doi.org/10.22159/ajpcr.2018.v11i10.19439

\section{INTRODUCTION}

Breast cancer is one of the most frequent cancers in women of the developed and developing countries. Oxygen free radicals are generated during various metabolic processes, and for the excess production of free radicals, an antioxidant defense mechanism is generated in the body [1]. Oxidative damage to cells and macromolecules is considered to be the cause of several diseases such as coronary heart disease, arthritis, and various neurodegenerative diseases including cancer [2]. Reactive oxygen species are involved in a variety of important pathophysiological conditions including mutagenesis and carcinogenesis.

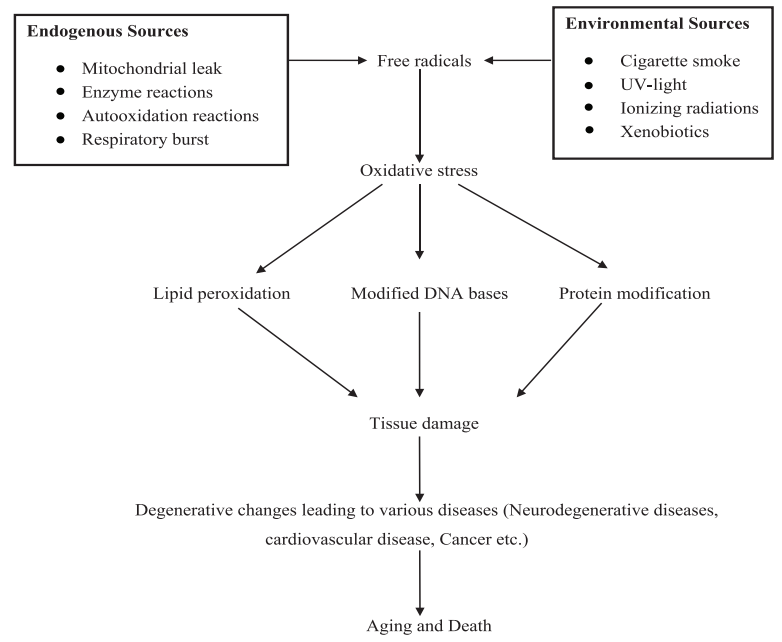

In addition, there are emerging evidences, suggesting that 7, 12- dimethylbenz $(\alpha)$ anthracene (DMBA) induces the production of reactive oxygen species (ROS) that result in lipid peroxidation, DNA damage, and depletion of cell's antioxidant defense systems [3]. Such alterations or imbalance in ROS and antioxidants can be balanced with the help of plants having antioxidant properties [4]. In recent days, plant-based therapies have emerged as a potential remedy for all human ailments including cancer [5]. Oxidative damage to biomolecules is caused due to the release of oxygen free radicals and oxidants which tend to generate oxidative stress [6,7]. The role of oxidative stress and lipid peroxidation in tumor development was studied in vivo [8]. There are certain detoxifying enzymes and small scavenger molecules at cellular levels acting as antioxidant defenses. The intracellular ROS-scavenging system includes superoxide dismutases (SOD), catalases (CAT), and glutathione peroxidase (GPx), which are potential free radical scavengers and are signified as cancer inhibitors at different stages of carcinogenesis [9]. Tinospora cordifolia is a widely used medicinal herb for its potential biological activity against numerous human disorders $[10,11]$. Various compounds explored from this plant have been recognized to possess several pharmacological activities [12], most importantly anti-diabetic [13] and anti-clastogenic [14] effects, and in such a way, the polysaccharide isolated from T. cordifolia has been experimentally reported to possess antidiabetic efficacy on type I diabetic animal models [15].

However, there are no proven evidences on the antioxidant potential of polysaccharide isolated from T. cordifolia, and hence, the present study was focused on identifying the antioxidant property of polysaccharide isolated from methanolic extract of T. cordifolia stem bark on MCF-7 and MDA-MB-231 cancer cell lines, and its in vivo activities on albino Wistar rat breast and liver tissues were also examined. 


\section{METHODS}

\section{Isolation of polysaccharide}

Polysaccharide was isolated from the methanolic extract of T. cordifolia stem bark, by the protocol of Rajalakshmi et al. [15].

\section{Cell line}

Human breast cancer cell lines (MCF-7 and MDA-MB-231) were procured from ATCC and were cultured in DMEM culture medium with $10 \% \mathrm{FBS}$ at $5 \% \mathrm{CO}_{2}$ and $37^{\circ} \mathrm{C}$. Cells were passaged using trypsin EDTA at $70-80 \%$ confluence.

\section{Compound preparation}

$1 \mathrm{mM}$ stock solutions of the polysaccharide were prepared with dimethyl sulfoxide (DMSO). From the stock, the compounds were prepared at different micromolar concentrations $(10,20,30,40,80$, and $100 \mu \mathrm{M}$ ) with serum-free medium for the test. The concentration of DMSO was aimed not to exceed $0.01 \%$.

\section{In vitro studies}

\section{Treatment protocol}

Cells were seeded in 6-well plate $\left(1.8 \times 10^{6}\right.$ cells/well $)$ in medium containing $10 \% \mathrm{FBS}$ and incubated for $24 \mathrm{~h}$ under $5 \% \mathrm{CO}_{2}$ at $37^{\circ} \mathrm{C}$ for attachment. The cells were then washed with $\times 1 \mathrm{PBS}$, and polysaccharide $(100 \mu \mathrm{M})$ was added to the wells containing MCF-7 cells and incubated for $24 \mathrm{~h}$. The medium was then removed, and the cells were washed with PBS. Finally, the cells were collected by adding trypsin EDTA, pelletized, and the supernatant was used for further assays.

\section{Determination of TBARS}

A lipid peroxide level was estimated by the method reported by Ohkawa et al. [16]. The assay mixture consisting of $0.1 \mathrm{~mL}$ of the cell and tissue lysate, $0.2 \mathrm{~mL}$ of $8.1 \%$ sodium dodecyl sulfate, $1.5 \mathrm{M}$ of $20 \%$ acetic acid (adjusted to pH 3.5 with $\mathrm{NaOH}$ ), and $1.5 \mathrm{~mL}$ of $0.8 \%$ aqueous solution of thiobarbituric acid was heated for $60 \mathrm{~min}$ at $95^{\circ} \mathrm{C}$. Thereafter, the mixture was cooled and extracted with $5 \mathrm{~mL}$ of a mixture of n-butanol and pyridine $(15: 1 \mathrm{v} / \mathrm{v})$. After centrifugation at $4000 \mathrm{rpm}$ for $10 \mathrm{~min}$, the organic phase was assayed spectrophotometrically at $532 \mathrm{~nm}$ and the lipid peroxide levels of TBARS were determined $(\mathrm{mmol} / \mathrm{mL})$.

\section{Determination of SOD}

SOD level was estimated by the method described by Kakkar et al. [17]. The assay mixture contained $0.1 \mathrm{~mL}$ of the cell and tissue lysate, $1.2 \mathrm{~mL}$ of sodium pyrophosphate buffer ( $\mathrm{pH} 8.3,0.025 \mathrm{M}), 0.1 \mathrm{~mL}$ phenazine methosulfate $(186 \mu \mathrm{M}), 0.3 \mathrm{~mL}$ of $300 \mu \mathrm{M}$ nitroblue tetrazolium, and $0.2 \mathrm{~mL}$ of NADH $(780 \mu \mathrm{M})$. The reaction was started by the addition of $\mathrm{NADH}$. After incubation at $30^{\circ} \mathrm{C}$ for $90 \mathrm{~s}$, the reaction was stopped by the addition of $1 \mathrm{~mL}$ glacial acetic acid. The reaction mixture was stirred vigorously with $4 \mathrm{ml}$ of $\mathrm{n}$-butanol, and the mixture was allowed to stand for $10 \mathrm{~min}$. After centrifuging the mixture, the n-butanol layer was separated. Color intensity of the chromogen in n-butanol was measured at $520 \mathrm{~nm}$ spectrophotometrically, and the concentration of SOD was expressed as unit $/ \mathrm{min} / \mathrm{mg}$ of protein.

\section{Determination of CAT}

CAT level was measured by the method described by Aebi et al. [18]. A volume of $0.1 \mathrm{~mL}$ of cell and tissue lysate was added to a cuvette containing $1.9 \mathrm{~mL}$ of $50 \mathrm{mM}$ phosphate buffer ( $\mathrm{pH}$ 7.0). A reaction was started by the addition of $1 \mathrm{~mL}$ of freshly prepared $30 \mathrm{mM} \mathrm{H}_{2} \mathrm{O}_{2}$. The rate of decomposition of $\mathrm{H}_{2} \mathrm{O}_{2}$ was measured spectrophotometrically from changes in absorbance at $240 \mathrm{~nm}$. The activity of CAT was expressed as $\mu$. mol $\mathrm{H}_{2} \mathrm{O}_{2}$ consumed/min mg protein.

\section{Assay of GPX}

GPx level was measured by the method described by Rotruck et al. [19]. To $0.2 \mathrm{~mL}$ of the cell and tissue lysate, $0.2 \mathrm{~mL}$ of $0.4 \mathrm{mM}$ EDTA, $0.1 \mathrm{~mL}$ of sodium azide, $0.2 \mathrm{~mL}$ of $2 \mathrm{mM} \mathrm{GSH}$, and $0.1 \mathrm{~mL}_{\mathrm{H}} 2_{\mathrm{O} 2}$ solution, $0.4 \mathrm{~mL}$ of $0.4 \mathrm{M}$ phosphate buffer ( $\mathrm{pH} 7.0$ ) was added. The mixture was incubated at $37^{\circ} \mathrm{C}$ for $10 \mathrm{~min}$, and $0.5 \mathrm{~mL}$ of $10 \%$ TCA was added and centrifuged at $2000 \mathrm{rpm}$ for $10 \mathrm{~min}$. The supernatant was collected and $0.1 \mathrm{~mL}$ of $0.04 \%$ DTNB solution was added to it. Optical density was read at $420 \mathrm{~nm}$ against blank, and the results were obtained. The activity of GPx was expressed as GSH utilized/min/mg of protein.

\section{In vivo studies}

\section{Animals}

Female albino Wistar rats aged between 50 and 55 days were procured from Tamil Nadu Veterinary Sciences, Madhavaram. The animals were maintained under controlled environmental conditions on alternative $12 \mathrm{~h}$ dark/light cycle. Commercial pelleted feed supplied by Sai Enterprises Ltd., Chennai, and water ad libitum were given to animals. This research work on albino Wistar rats was sanctioned and approved by the Institutional Animal Ethical Committee (IAEC No. 07/2013).

\section{Experimental setup}

The animals were divided into five groups of five animals each. Group I animals served as normal control, Group II was normal animals supplemented with polysaccharide $(20 \mathrm{mg} / \mathrm{kg}$ body weight [bwt]), Group III was animals treated with $20 \mathrm{mg}$ of DMBA in $1 \mathrm{~mL}$ corn oil to induce breast cancer, Group IV animals were treated with DMBA and simultaneously supplemented with polysaccharide $(20 \mathrm{mg} / \mathrm{kg} \mathrm{bwt})$, and Group V animals were treated with DMBA and simultaneously supplemented with paclitaxel ( $1 \mathrm{mg} / \mathrm{kg}$ bwt). The overall induction and treatment period was 3 months for all groups. After the experimental period, the animals were sacrificed by decapitation, breast and liver tissues were dissected out, and tissue homogenates were prepared in $0.1 \mathrm{M}$ Tris- $\mathrm{HCl}$ buffer $\mathrm{pH} 7.4$ which was stored at $80^{\circ} \mathrm{C}$, until its use for further analysis.

\section{Antioxidant enzyme analysis}

The breast and liver tissue homogenates were used for the estimation of antioxidant levels such as SOD [17], CAT [18], GPx [19], and lipid peroxidation (LPO) [16].

\section{Statistical analysis}

The data were analyzed using the SPSS Windows Students version software. For all the measurement, one-way ANOVA followed by Student-Newman-Keuls (SNK) test was used to assess the statistical significance of the difference between control and treated groups. A statistically significant difference was considered at the level of $\mathrm{p}<0.05$.

\section{RESULTS}

\section{Effect of polysaccharide on TBARS level}

Analysis of TBARS is the widely used method for the evaluation of lipid peroxidation. TBARS level in breast cancer cell lines was found to be altered, and a significant decrease in the levels was examined on treatment with $100 \mu \mathrm{M}$ polysaccharide in both MCF-7 and MDAMB-231 cell lines (Fig. 1). In vivo experiments on breast and liver tissues (Fig. 2) observed a significant increase in lipid peroxidation level in DMBA-induced rats (Group III) when compared to normal (Group I) animals. No such significant increase in TBARS level was observed in polysaccharide-supplemented DMBA-induced animals (Group IV). Group I and Group V (standard drug-paclitaxel supplemented DMBAinduced animals) showed normal level of lipid peroxidation. Hence, the results suggested that the polysaccharide regulates a normal lipid peroxidation level in both in vitro and in vivo conditions.

\section{Effect of polysaccharide on SOD, CAT, and GPx levels}

Variation in the activities of antioxidant enzymes such as SOD, CAT, and GPx that is usually found at lower levels in cancer conditions was examined. A significant increase in the activity of antioxidant enzymes was noted on polysaccharide-treated MCF-7 and MDA-MB-231 cell lines, when compared with the cancer control cells (Fig. 3). It is also proved through the in vivo studies on the breast (Fig. 4) and liver tissues (Fig. 5). Similarly, increase in the activity of these antioxidant enzymes was identified in polysaccharide-treated DMBA-induced animals and it was maintained near to normal, whereas DMBA-induced animals had a 


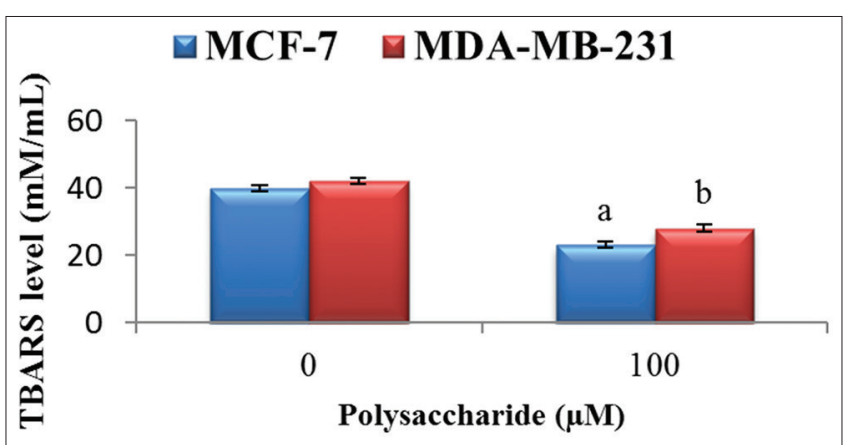

Fig. 1: Effect of polysaccharide on TBARS level of MCF-7 and MDA-MB-231 cells. Each bar represents the mean \pm SEM of five independent observations. Statistical significance at $\mathbf{p}<0.05$, (a) compared with MCF-7 control, (b) compared with MDA-MB-231 control

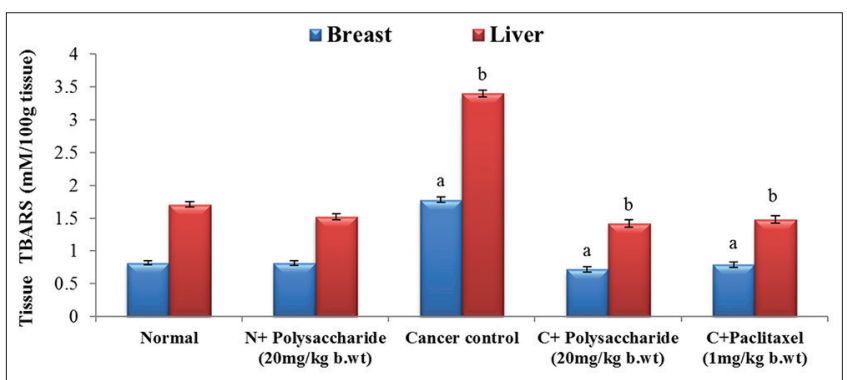

Fig. 2: Effect of polysaccharide on lipid peroxidation in the breast and liver tissues of control and experimental animals. Each value is expressed as mean \pm SEM for five animals in each group. Statistical significance at $\mathbf{p}<0.05$, (a) compared with breast control, (b) compared with liver control reduction in the level of these enzymes. Therefore, it is suggested that normal levels of SOD, CAT, and GPx levels were maintained in both in vitro and in vivo conditions with polysaccharide treatment.

\section{DISCUSSION}

Natural antioxidants are characterized by their ability to scavenge free radicals. Medicines from herbal resources are preferred over the synthetic drugs for their better bioavailability and minimal side effects [20]. Plants that possess anticancer activity are also found to have a potential antioxidant activity, which is correlated with the cytotoxic efficacy of the molecules [21]. Many studies have found that the antioxidant property of a plant has a potential role in inhibiting the growth of cancer cells. In this study, the antioxidant potential of the polysaccharide isolated from the methanolic extract of T. cordifolia stem bark was studied on MCF-7 and MDA-MB-231 cell lines and on female albino Wistar rat breast and liver tissues.

Oxidative stress, which causes the development of cancer, is created by various underlying factors which include the excessive production of ROS that is responsible for the high level of lipid peroxidation and a deficit in antioxidant balance [22,23]. Antioxidant-rich plants are capable to inhibit the growth of several cancer cell lines, including breast cancer [24]. From the present study, it is found that, both in the in-vitro and in-vivo conditions, the level of lipid peroxidation was decreased and the level of antioxidant enzymes was increased in the polysaccharide-treated group of animals.

The SOD activity was very low in almost all types of cancer which indicates the reduction in the ROS defending mechanisms, and this low level of SOD leads to the increase of superoxide anions which in turn promotes cancer cell proliferation by acting as a second messenger. Inhibition of the development of cancer can be brought about by the increased level of SOD. The results of this study proved that the polysaccharide treatment increased the level of SOD in the cancer cell lines.

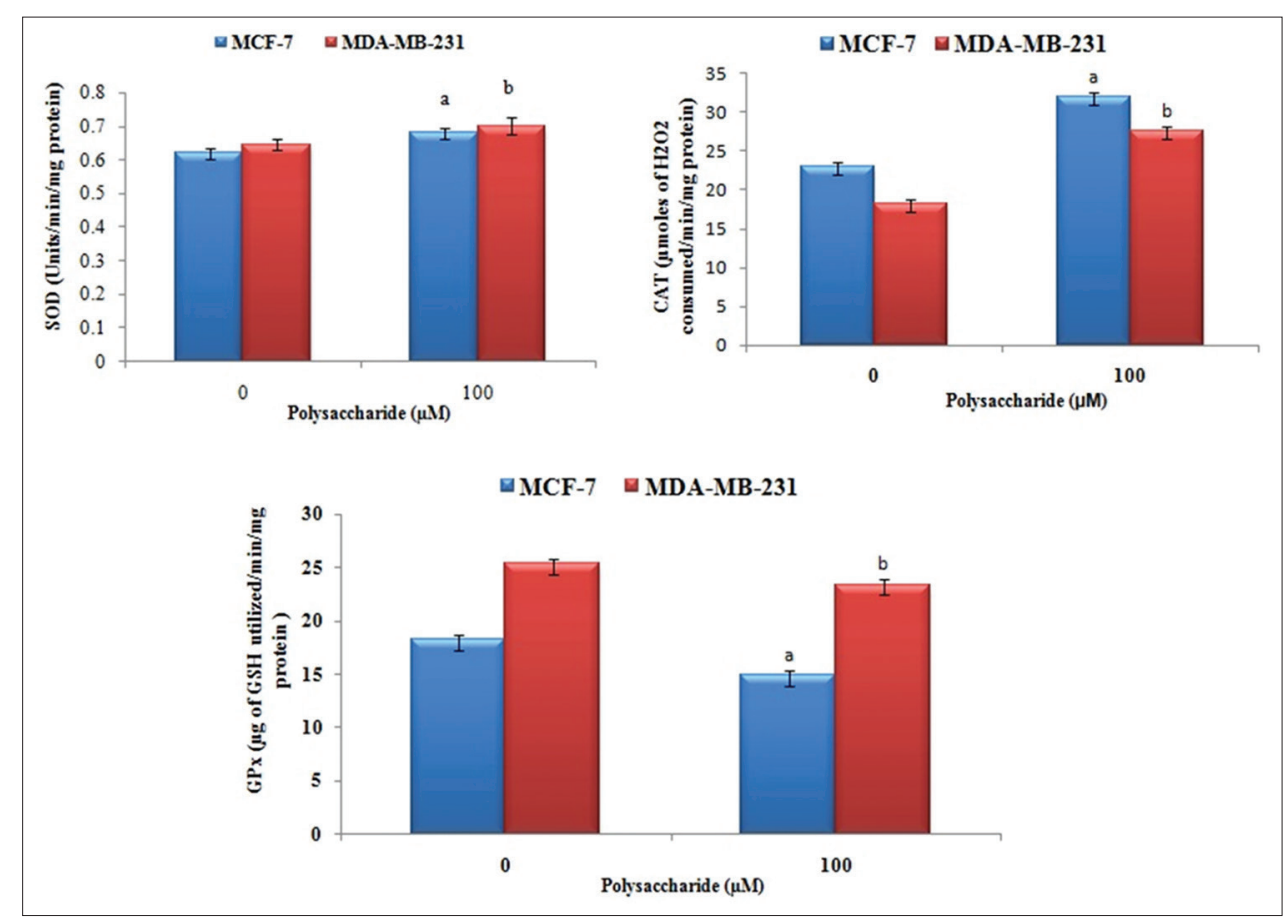

Fig. 3: Effect of the polysaccharide on antioxidants in MCF-7 and MDA-MB-231 cells. Units SOD: Unit/min/mg protein. CAT: $\mu$.mol $\mathrm{H} 202$ consumed/min $\mathrm{mg}$ protein. GPx: $\mu \mathrm{g}$ of GSH utilized $/ \mathrm{min} / \mathrm{mg}$ protein. Each bar represents the mean \pm SEM of five independent observations. Statistical significance at $\mathbf{p}<0.05$, (a) compared with MCF-7 control, (b) compared with MDA-MB-231 control 


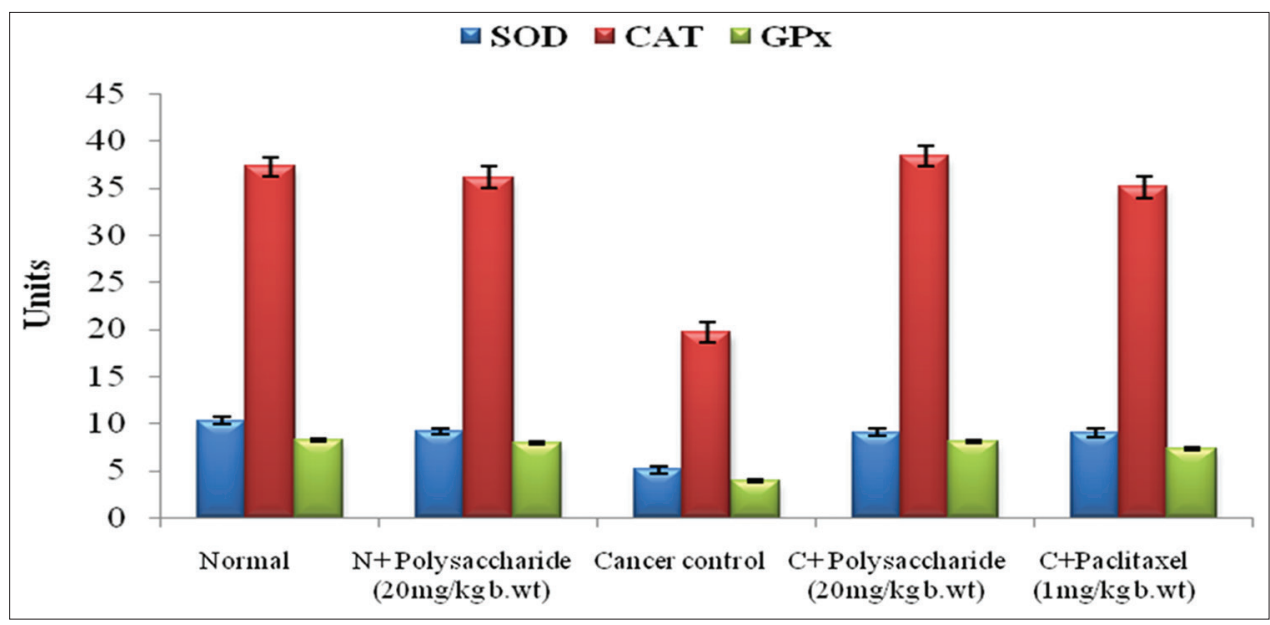

Fig. 4: Effect of the polysaccharide on antioxidants in female albino Wistar rat breast tissue. Units - SOD: Unit/min/mg protein. CAT: $\mu$.mol H202 consumed/min $\mathrm{mg}$ protein. GPx: $\mu \mathrm{g}$ of GSH utilized $/ \mathrm{min} / \mathrm{mg}$ protein. Each value is expressed as mean \pm SEM of five animals in each group

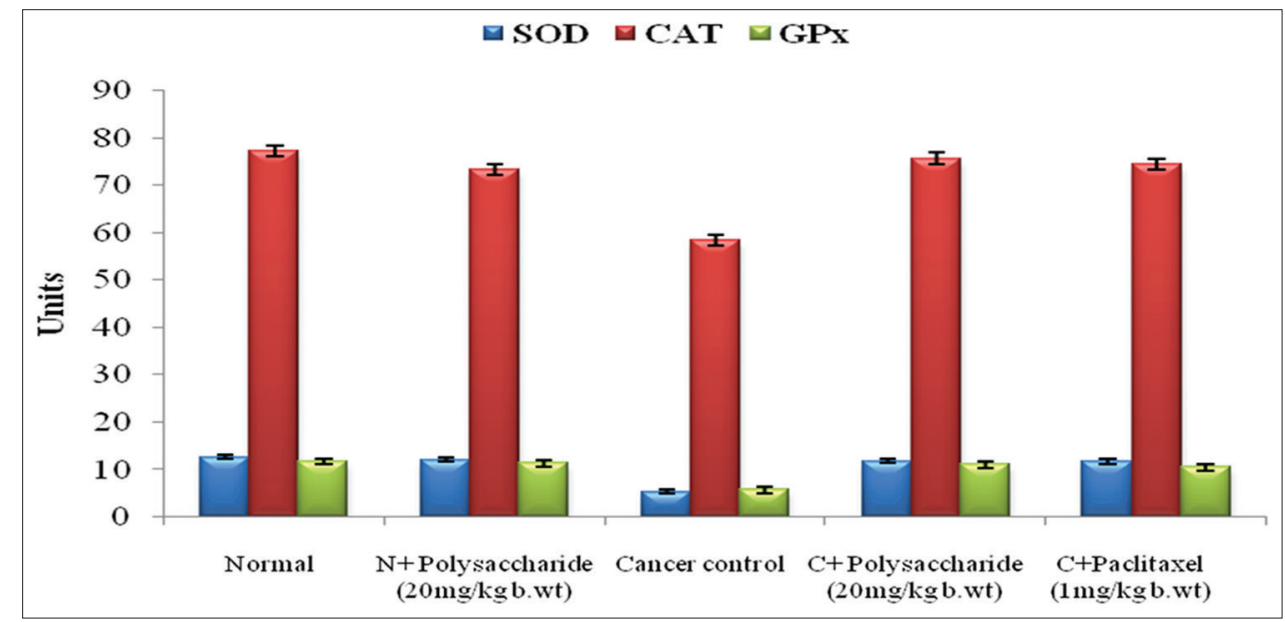

Fig. 5: Effect of the polysaccharide on antioxidants in female albino Wistar rat liver tissue. Units - SOD: Unit/min/mg protein. CAT: $\mu$.mol H202 consumed $/ \mathrm{min} \mathrm{mg}$ protein. GPx: $\mu \mathrm{g}$ of GSH utilized $/ \mathrm{min} / \mathrm{mg}$ protein. Each value is expressed as mean \pm SEM of five animals in each group

An anticancer agent with antioxidant activities balances the ROS levels, inhibits further proliferation of cancer cells, and allows apoptosis to occur. Besides, polysaccharide-treated MCF-7 and MDA-MB-231 cells enhanced the levels of the antioxidant enzymes and thereby decreased the oxidative stress. Increase in SOD and CAT is reported to inhibit tumor progression with less proliferation and migration of the cancer cells $[25,26]$. In the present study, there was a significant increase in the CAT levels in the polysaccharide-treated cancer cell lines when compared to DMBA-induced cancer groups.

GPx inhibits cancer initiation and metastasis in many of the cancers [27]. This may be due to the reduction of ROS-mediated DNA damage or mutations that induce carcinogenesis. Thus, the increase in the antioxidant enzymes activity is attributed to the induction of cell apoptosis. In this study, GPx levels in the polysaccharide-treated cancer groups were increased which were initially low.

Thus, the polysaccharide-treated groups exhibited normal range of lipid peroxidation and antioxidant levels. These alterations maintained a normal balance between the antioxidant defense system and the ROS generation, thereby inhibiting the cancer cell proliferation of MCF-7 and MDA-MB-231 cell lines.

\section{CONCLUSION}

Thus, the present study proved that the polysaccharide isolated from the methanolic extract of $T$. cordifolia stem bark has an efficient antioxidant property on both in vitro cell lines and in vivo animal models. Elevated levels of lipid peroxidation and decreased activities of antioxidant enzymes in both MCF-7 and MDA-MB-231 cell lines and in breast and liver tissues of DMBA-induced breast cancer female albino Wistar rats were prevented on treatment with the compound. Thus, it is evident that the abnormality with ROS and antioxidant enzymes was normalized by the polysaccharide which subsequently resulted in the inhibition of cancer. Hence, the novel polysaccharide can be used as an antioxidant agent with further explorations.

\section{ACKNOWLEDGMENT}

The work was supported by the grant from the University Grants Commission (UGC) (F. No. MRP- 5094/14 (SERO/UGC) and DBT-BIF, Ministry of Science and Technology, Government of India, New Delhi, for infrastructure facility.

\section{AUTHOR'S CONTRIBUTION}

Research guidance - Manikkam Rajalakshmi. Laboratory and experimental work and writing the article - Antony Ludas. Manuscript writing - Sabapathy Indu. Laboratory work - Sekar Hinduja. Laboratory work - Anthonisamy Kumari Nirmala.

\section{CONFLICTS OF INTEREST}

All authors have none to declare. 


\section{REFERENCES}

1. Rahal A, Kumar A, Singh V, Yadav B, Tiwari R, Chakraborty S, et al. Oxidative stress, prooxidants, and antioxidants: The Interplay. Biomed Res Int 2014;2014:1-19.

2. Lobo V, Patil A, Phatak A, Chandra N. Free radicals, antioxidants and functional foods: Impact on human health. Pharmacogn Rev 2010;4:118-26.

3. Bharali R, Tabassum J, Azad MR. Chemomodulatory effect of Moringa oleifera, lam, on hepatic carcinogen metabolising enzymes, antioxidant parameters and skin papillomagenesis in mice. Asian Pac J Cancer Prev 2003;4:131-9.

4. Aruoma OI. Nutrition and health aspects of free radicals and antioxidants. Food Chem Toxicol 1994;32:671-83.

5. Cerutti PA. Prooxidant states and tumor promotion. Science $1985 ; 227: 375-81$.

6. Halliwell B, Gutteridge MC. Free Radicals in Biology and Medicine. $3^{\text {rd }}$ ed. London: Oxford; 1999.

7. Diplock AT, Rice-Evans CA, Burton RH. Is there a significant role for lipid peroxidation in the causation of malignancy and for antioxidants in cancer prevention? Cancer Res 1994;54:1952-6.

8. Wang M, Dhingra K, Hittelman WN, Liehr JG, de Andrade M, Li D, et al. Lipid peroxidation-induced putative malondialdehyde-DNA adducts in human breast tissues. Cancer Epidemiol Biomarkers Prev 1996;5:705-10.

9. Sun Y. Free radicals, antioxidant enzymes, and carcinogenesis. Free Radic Biol Med 1990;8:583-99.

10. Enespa DS. Tinospora cordifolia with reference to biological and microbial properties. Int J Curr Microbiol App Sci 2016;5:446-65.

11. Reddy NM, Rajasekhar Reddy N. Tinospora cordifolia chemical constituents and medicinal properties: A review. Sch Acad J Pharm 2015;4:364-9.

12. Neeraja PV, Margaret E. Amruthavalli (Tinospora cordifolia) multipurpose rejuvenator. Int J Pharm Chem Biol Sci 2013;3:233-41.

13. Pujiyanto S, Lestari Y, Suwanto A, Budiarti S, Darusman LK. Alphaglucosidase inhibitor activity and characterization of endophytic actinomycetes isolated from some Indonesian diabetic medicinal plants. Int J Pharm Pharm Sci 2012;4:327-33.

14. Ambasta SK, Kumari S, Sinha UK. Anticlastogenicity of Tinospora cordifolia stem extract against arsenic genotoxicity in Mus musculus bone marrow erythrocytes using micronucleus assay. Int J Pharm Pharm Sci 2017;9:260-4.

15. Rajalakshmi M, Eliza J, Priya CE, Nirmala A, Daisy P. Anti-diabetic properties of Tinospora cordifolia stem extracts on streptozotocininduced diabetic rats. Afr J Pharm Pharmacol 2009;3:171-80.

16. Ohkawa H, Ohishi N, Yagi K. Assay for lipid peroxidase in animal tissue by thiobarbituric acid reaction. Anal Biochem 1979;95:351-8.

17. Kakkar P, Das B, Viswanathan PN. A modified spectrophotometric assay of superoxide dismutase. Indian J Biochem Biophys 1984;21:130-2.

18. Aebi H. Catalase. In: Methods in Enzymatic Analysis. Verlag: Chemic Academic Press Inc.; 1974

19. Rotruck JT, Pope AL, Ganther HE, Swanson AB, Hafeman DG, Hoekstra WG, et al. Selenium: Biochemical role as a component of glutathione peroxidase. Science 1973;179:588-90.

20. Yuan H, Ma Q, Ye L, Piao G. The traditional medicine and modern medicine from natural products. Molecules 2016;21: pii: E559.

21. Abrahim NN, Kanthimathi MS, Abdul-Aziz A. Piper betle shows antioxidant activities, inhibits MCF-7 cell proliferation and increases activities of catalase and superoxide dismutase. BMC Complement Altern Med 2012;12:220.

22. Szatrowski TP, Nathan CF. Production of large amounts of hydrogen peroxide by human tumor cells. Cancer Res 1991;51:794-8.

23. Banerjee A, Maji B, Mukherjee S, Chaudhuri K, Seal T. In vitro antidiabetic and anti-oxidant activities of ethanol extract of Tinospora sinensis. Int J Curr Pharm Res 2017;9:42-7.

24. Seeram NP, Adams LS, Zhang Y, Lee R, Sand D, Scheuller HS, et al. Blackberry, black raspberry, blueberry, cranberry, red raspberry, and strawberry extracts inhibit growth and stimulate apoptosis of human cancer cells in vitro. J Agric Food Chem 2006;54:9329-39.

25. Li Z, Khaletskiy A, Wang J, Wong JY, Oberley LW, Li JJ. Genes regulated in human breast cancer cells overexpressing manganesecontaining superoxide dismutase. Free Rad Biol Med 2001;30:260-7.

26. Glorieux C, Dejeans N, Sid B, Beck R, Calderon PB, Verrax J, et al. Catalase overexpression in mammary cancer cells leads to a less aggressive phenotype and an altered response to chemotherapy. Biochem Pharmacol 2011;82:1384-90.

27. Brigelius-Flohé R, Kipp A. Glutathione peroxidases in different stages of carcinogenesis. Biochim Biophys Acta 2009;1790:1555-68. 